\title{
FAKTOR-FAKTOR YANG MEMENGARUHI KEBERHASILAN REDENOMINASI
}

\author{
Nur Siti Annazah ${ }^{1}$, Bambang Juanda ${ }^{2}$, Sri Mulatsih ${ }^{2}$ \\ ${ }^{1}$ Mahasiswa Magister Program Studi Ilmu Ekonomi, FEM IPB \\ ${ }^{2}$ Staf Pengajar FEM IPB
}

\begin{abstract}
Redenomination is a simplification of the nominal value of the currency by reducing digits (zeros) without reducing the real value of the currency. The research was done because of the theoretical and empirical results are still a debate about the impact of redenomination policy on the economic perspective. This is due to the redenomination policy in each country has a different effect depending on economic conditions when redenomination is applied. The purpose of this study was to analyze the factors that influence the success of the redenomination of a country. Data used in the form of secondary data, historical data of 32 countries that have conducted redenomination. The analysis used is multiple regression. The results showed the better the condition of economic growth when redenomination is applied, it will lower inflation one year after the redenomination.
\end{abstract}

Keywords: Economic growth, Inflation, Redenomination, Regression

\section{PENDAHULUAN}

\section{Latar Belakang}

Wacana redenominasi muncul sejak pemerintahan Presiden Susilo Bambang Yudhoyono tahun 2010. Pada tanggal 03 Agustus 2010, Gubernur Bank Indonesia Darmin Nasution mengumumkan akan melakukan redenominasi mata uang Rupiah. Menururt Darmin, Indonesia perlu melakukan redenominasi untuk menghadapi tantangan ke depan berupa integrasi perekonomian regional. ${ }^{\mathrm{i}} \mathrm{Hal}$ ini menimbulkan banyak pertanyaan terkait dampak redenominasi. Wacana adanya redenominasi akan menimbulkan pro dan kontra karena sebagian besar masyarakat menganggap bahwa redenominasi sama dengan sanering (Lianto dan Ronald, 2012).

Redenominasi merupakan istilah penyederhanaan nilai nominal mata uang dengan mengurangi digit (angka nol) tanpa mengurangi nilai riil mata uang (Bank Indonesia, 2017). Sedangkan sanering adalah memotong nilai uang sebesar $90 \%$ dari nilai nominal serta membekukan simpanan masyarakat untuk dijadikan simpanan jangka panjang. Indonesia pernah melakukan sanering mata uang pada tahun 1959. Kebijakan ini meyebabkan bank-bank mengalami kesulitan likuiditas.

Urgensi pelaksanaan redenominasi di Indonesia didasari adanya inefisiensi perekonomian, adanya kendala teknis pada operasional kegiatan usaha dan mendukung ekonomi nasional dalam memasuki era Masyarakat Ekonomi Asean (MEA). Redenominasi diharapkan dapat memberi manfaat positif bagi negara, pelaku usaha, dan masyarakat. Manfaat redenominasi bagi negara adalah dapat meningkatkan kredibilitas 
rupiah, menghemat biaya pencetakan uang, dan mempermudah transaksi pemerintah. Bagi pelaku usaha redenominasi dapat mempermudah transaksi keuangan sehingga mempercepat waktu operasional dan meminimalisir potensi kesalahan. Selain itu, redenominasi akan mengurangi biaya penyesuaian perangkat keras dan lunak sistem akuntansi dan teknologi informasi. Bagi masyarakat, redenominasi dapat mempermudah dalam bertransaksi.

Tabel 1 Mata uang dengan nominal pecahan terbesar

\begin{tabular}{llc}
\hline No & $\begin{array}{c}\text { Mata Uang } \\
\text { (Negara) }\end{array}$ & Nominal \\
\hline 1 & Dong (Vietnam) & 500.000 \\
2 & Rubel (Belarus) & 200.000 \\
3 & Rupiah(Indonesia) & 100.000 \\
4 & Rial (Iran) & 100.000 \\
5 & Korea (Won) & 50.000 \\
\hline Ket & : Nominal pechan uang terbesar
\end{tabular}

Saat ini pecahan $\mathrm{Rp} 100.000,00$ merupakan pecahan mata uang terbesar ke-3 setelah mata uang Dong (Vietnam) dan Rubel (Rusia). Apabila Indonesia terus mengalami inflasi, maka tidak menutup kemungkinan akan muncul pecahan Rupiah baru yang lebih besar. Nilai nominal yang terlalu besar menunjukkan bahwa suatu negara pernah mengalami kondisi fundamental perekonomian yang kurang baik. Nilai nominal suatu Negara yang semakin besar disebabkan karena di masa lampau terjadi kesalahan kebijakan yang dilakukan oleh pemerintah. Hal tersebut menyebabkan inefisiensi transaksi perekonomian karena penggunaan mata uang yang relatif kurang efisien. Redenominasi dapat mencegah terjadinya kendala teknis akibat jumlah digit yang besar.
Tabel 2 Mata uang dengan nilai tukar terendah

\begin{tabular}{llc}
\hline No & \multicolumn{1}{c}{$\begin{array}{c}\text { Mata Uang } \\
\text { (Negara) }\end{array}$} & $\begin{array}{c}\text { Nilai Tukar } \\
\text { Terhadap } \\
\text { 1US \$ }\end{array}$ \\
\hline 1 & Rial (Iran) & 32.466 \\
2 & Dong (Vietnam) & 22.699 \\
3 & Rubel (Belarusia) & 18.936 \\
4 & Rupiah(Indonesia) & 13.340 \\
5 & Boliviar(Venezuela) & 9.993 \\
\hline
\end{tabular}

Sumber: http://id.rateq.com

Selain itu, nilai tukar Rupiah terhadap Dollar Amerika (US\$) merupakan nilai tukar terendah ke-4. Tabel 2 menunjukkan lima mata uang dengan nilai tukar terendah terhadap Dollar Amerika. Masalah tersebut akan mengakibatkan kurangnya kepercayaan masyarakat terhadap Rupiah sehingga masyarakat akan lebih menyukai memiliki mata uang asing. Kepercayaan masyarakat suatu negara terhadap mata uangnya sangat penting karena dapat menjaga stabilitas ekonomi negara dengan mengendalikan penggunaan mata uang asing. Selain itu, kredibilitas pemerintah dalam menetapkan kebijakan baik moneter atau fiskal juga akan berkurang apabila masyarakat lebih menyukai memegang uang asing. Inflasi yang tinggi serta melemahnya nilai tukar terhadap mata uang lainnya merupakan masalah bagi negara berkembang. Mosley (2005) menjelaskan bahwa inflasi yang tinggi merupakan alasan untuk melakukan redenominasi. Inflasi juga merupakan salah satu indikator yang menunjukkan keberhasilan redenominasi. Apabila tingkat inflasi menjadi lebih rendah dan stabil setelah kebijakan redenominasi diterapkan, maka negara tersebut dianggap berhasil. Sebaliknya, negara dianggap gagal jika tingkat inflasi menjadi lebih tinggi dan cenderung tidak stabil. 
Terdapat 55 negara yang telah melakukan redenominasi sejak tahun 1923 (Iona 2005). Negara yang dianggap berhasil dalam menerapkan kebijakan redenominasi diantaranya adalah Argentina, 2013), Rumania dan Polandia (Daniel, 2013) dan Brazil (Iona 2005). Sedangkan negara yang gagal dalam melakukan redenominasi diataranya adalah Congo (Iona 2005) dan Zimbabwe.

Polandia, Turki, dan Rumania berhasil melakukan redenominai secara langsung. Polandia berhasil menghilangkan 4 angka nol pada tahun 1995. Kondisi perekonomian Polandia berangsur membaik dengan tingkat inflasi dari tahun 1995 sampai 2014 rata-rata sebeser 5\%. Sebagai perbandingan sebelum redenominasi rata-rata tingkat inflasi sebesar $40 \%$ dari tahun 1991 sampai 1994. Turki melakukan redenominasi karena laju inflasi yang terus meningkat sejak tahun 1970 yang mencapai $137 \%$ pada tahun 1998. Turki melakukan redenominasi mata uang Lira tahun 2005 (Zidek \& Chribik 2015).

Keadaan perekonomian Turki sejak tahun 2005 tetap terjaga dengan rata-rata inflasi tahun 2005 sampai dengan tahun 2015 sebesar $7.5 \%$. Terinspirasi kesuksesan redenominasi di Turki, Gubernur Bank Nasional Rumania melakukan redenominasi mata uang Lei tanggal 1 Juli 2005. Redenominasi di Rumania menunjukkan hasil yang memuaskan dengan nilai tukar yang menguat. Sebelum redenominasi, nilai tukar terhadap US\$ sebesar 29,891 Lei dan terhadap Euro sebesar 36,050 Lei. Setelah Redenominasi mata uang Rumania menguat terhadap US\$ menjadi 2,98 Lei dan terhadap Euro 3,6 Lei (Daniel, 2013).

Brazil dan Argentina sukses melakukan redenominasi setelah melakukan beberapa kali redenominasi. Brazil melakukan redenominasi dengan menghilangkan 18 angka nol secara bertahap tahun 1967, 1970, 1986, 1989, 1993, dan 1994. Redenominasi Brazil berhasil setelah tahun 1994 dimana Brazil melakukan redenominasi yang terakhir dengan menghilangkan 3 angka nol. Tingkat inflasi Brazil mengalami penurunan sebelum dan setelah redenominasi.

Pertumbuhan tingkat inflasi Brazil dari tahun 1995 sampai 2014 (pasca redenominasi) adalah sebesar $14 \%$. Sebagai perbandingan, tingkat inflasi Brazil tahun 1994 (sebelum redenominasi) adalah sebesar $2075 \%$. Sama halnya dengan Brazil, Argentina juga sukses melaksanakan redenominasi setelah 4 kali memotong angka nol pada nominal mata uangnya. Argentina menghilangkan 2 angka nol pertama tahun 1970. Tahun 1983 Argentina melakukan redenominasi yang kedua dengan menghilangkan 4 angka nol. Redenominasi yang ketiga dilakukan pada tahun 1985 dengan menghilangkan 3 angka nol. Argentina sukses melakukan redenominasi angka nol pada tahun 1992 dengan menghilangkan 4 angka nol terakhir Tingkat inflasi di Argentina mengalami penurunan setelah redenominasi diterapkan. Rata-rata tingkat inflasi di Argentina dari tahun 1993 sampai 2002 adalah sebesar 4,2\%.

Congo dan Zimbabwe adalah contoh negara yang tergolong gagal dalam melakukan redenominasi. Congo melakukan redenominasi secara bertahap dengan menghilangkan 14 angka nol mata uangnya berturut-turut. Pada tahun 1967 Congo menghilangkan 3 angka nol, dilanjutkan menghilangkan 6 angka nol tahun 1993 dan 5 angka nol terakhir dihilangkan pada tahun 1998. Redenominasi Congo tergolong gagal sebab tingkat inflasi pasca redenominasi mengalami peningkatan dengan rata-rata 
sebesar 240,63\%. Sebagai perbandingan, sebelum redenominasi tingkat inflasi Congo adalah sebesar 16,70\%. Gambar 3 menunjukkan tingkat inflasi Congo dari tahun 1996 sampai 2000.

Sama halnya dengan Congo, tingkat inflasi yang tinggi merupakan permasalahan yang utama bagi Zimbabwe. Tahun 2006 Zimbabwe melakukan redenominasi mengakibatkan tingkat inflasi sebesar 1097\% dibandingkan tahun sebelumnya. Redenominasi akan berdampak buruk apabila diterapkan pada saat tingkat inflasi yang tinggi. Sebaliknya ketika redenominasi diterapkan pada saat tingkat inflasi yang rendah maka akan memperbaiki kondisi perekonomian suatu negara. Selain itu, jumlah penghilangan angka nol dan tahapan redenominasi juga dapat memengaruhi keberhasilan redenominasi.

Keberhasilan redenominasi sangat dipengaruhi oleh kondisi perekonomian pada saat suatu negara menerapkan redenominasi mata uangnya. Pelaksanaan kebijakan redenominasi mata uang adalah kondisi perekonomian pada saat dilaksanakannya kebijakan tersebut. Lebih lanjut Pelaksanaan redenominasi lebih baik diterapkan ketika perekonomian berada dalam kondisi yang baik dan stabil, seperti tingkat inflasi yang rendah dan pertumbuhan ekonomi yang tinggi.

Hal ini sejalan dengan Iona (2005) yang menyebutkan bahwa suksesnya redenominasi hanya jika memenuhi dua kondisi. Pertama, tingkat inflasi yang rendah dengan kecenderungan yang menurun. Kedua, berhasilnya program reformasi dan restrukturisasi ekonomi, seperti pertumbuhan PDB riil yang tinggi. Jika kedua kondisi tersebut tidak dipenuhi maka redenominasi tidak akan berhasil dilakukan.
Kondisi perekonomian Indonesia sampai saat ini mengalami beberapa kali guncangan. Nilai tukar, inflasi, dan pertumbuhan ekonomi merupakan indikator penting yang memengaruhi kondisi perekonomian suatu negara Tujuan Bank Indonesia menurut UU No.23 tahun 1999 sebagaimana telah diamandemen menjadi UU No.3 tahun 2004 dan No. 6 tahun 2009 adalah mencapai dan memelihara kestabilan nilai Rupiah. Saat ini nilai tukar Rupiah membaik secara signifikan. Nilai tukar yang stabil adalah indikator kesuksesan Bank Indonesia dalam melaksanakan kebijakan moneter. Apabila nilai tukar Rupiah terapresiasi, maka Indonesia memiliki kekuatan di mata dunia.

Perkembangan nilai tukar dipengaruhi oleh kondisi inflasi. Perkembangan inflasi di Indonesia pasca kemerdekaan berfluktuasi. Setelah pemerintah melakukan sanering mata uang, inflasi di Indonesia cenderung tinggi. Puncaknya, Indonesia mengalami hiperinflasi pada tahun 1966 dimana tingkat inflasi mencapai $1136 \%$. Apabila negara memiliki historis tingkat inflasi yang tinggi, maka nilai tukar negara tersebut akan terdepresiasi. Melemahnya nilai tukar menyebabkan kekhawatiran kredibilitas pemerintah dan pengaruh mata uang pada identitas nasional (Mosley 2005). Saat ini, nilai tukar rupiah mencapai Rp13 400 per US\$. Rencana redenominasi bertujuan untuk me-ningkatkan martabat mata uang Rupiah.

Diperlukan kondisi makroekonomi yang sehat apabila kebijakan redenominasi diberlakukan. Kondisi ini ditunjukkan dengan tingkat inflasi dan pertumbuhan ekonomi yang stabil. Bank Indonesia menganggap bahwa saat ini adalah kondisi yang baik untuk melakukan redenominasi karena tingkat inflasi cenderung menurun dan laju pertumbuhan ekonomi semakin 
menguat. Tingkat inflasi Indonesia bertipe Creeping Inflation, yaitu inflasi yang berada di sekitar satu digit setiap tahunnya.

Selain inflasi, kondisi pertumbuhan ekonomi juga harus diperhatikan dalam melaksanakan redenominasi. Pertumbuhan ekonomi Indonesia tahun 1999-2014 menunjuk-kan kondisi yang stabil. Pertumbuhan ekonomi Indonesia rata-rata sebesar 5\%. Pertumbuhan ekonomi Indonesia dari tahun 1999 sampai 2014 memiliki tren yang cenderung meningkat tetapi pada tahun 2008 pertumbuhan ekonomi mengalami penurunan sebagai akibat dari krisis ekonomi global. Pertumbuhan ekonomi Indonesia lebih tinggi dibandingkan negara lain khususnya negara yang tergabung kedalam kelompok G8 (Kanada, Jerman, Perancis, Amerika Serikat, Italia, Jepang, Rusia, dan Inggris).

Adanya teori dan hasil empiris yang masih menjadi perdebatan mengenai dampak kebijakan redenominasi terhadap kinerja perekonomian. Hal ini dikarenakan kebijakan redenominasi di setiap negara memiliki pengaruh yang berbeda-beda. Perbedaan ini disebabkan karena keberhasilan redenominasi dipengaruhi oleh kondisi perekonomian ketika redenominasi diterapkan. Sehingga penelitian ini pada akhirnya dapat memberikan sebuah kesimpulan penting apakah kebijakan redenominasi dapat memperbaiki kondisi perekonomian di Indonesia.

\section{Tujuan Penelitian}

Berdasarkan uraian diatas maka tujuan penelitian adalah Mengidentifikasi faktor-faktor apa saja yang dapat memengaruhi keberhasilan penerapan kebijakan redenominasi di suatu negara.

\section{TINJAUAN PUSTAKA}

\section{Keterkaitan Redenominasi dengan Kinerja Perekonomian}

Sampai saat ini belum banyak studi terkait dampak kebijakan redenominasi terhadap kinerja perekonomian. Namun ada beberapa penelitian yang menyatakan bahwa kondisi negara memengaruhi kesuksesan kebijakan redenominasi. selain itu, redenominasi juga dipengaruhi oleh faktor-faktor lain yang berkaitan dengan kinerja perekonomian.

Kondisi ekonomi suatu negara memengaruhi kesuksesan kebijakan redenomi. Menggunakan data historis 30 negara yang pernah melakukan redenominasi. Hasil penelitian menunjukkan bahwa pertumbuhan ekonomi suatu negara yang melakukan redenominasi akan meningkat lebih tinggi apabila pertumbuhan ekonomi sebelum kebijakan redenominasi juga tinggi dan tingkat inflasi rendah.

Mosley (2005) menyatakan bahwa inflasi merupakan prediktor terpenting dari dilakukan atau tidaknya redenominasi. Zidek dan Chribik (2015) melakukan penelitian terkait redenominasi di Turki. Inflasi yang tinggi akibat krisis di Turki tahun 2001 mendorong Turki untuk melakukan kebijakan redenominasi. Hasil penelitian menunjukkan bahwa kebijakan redenominasi memiliki dampak langsung pada inflasi di Turki.

Dampak penerapan kebijakan redenominasi. Bagi negara pelaksanaan kebijakan redenominasi dapat memberikan implikasi positif, yaitu: (1) Meningkatkan kredibilitas Rupiah; (2) Menghemat biaya percetakan uang; (3) Mempermudah transaksi pemerintah. Bagi pelaku usaha redenominasi dapat meningkatkan efisiensi proses input data, pengelolaan database dan pelaporan data. Selain itu redenominasi 
dapat mengurangi biaya penyesuaian perangkat keras dan perangkat lunak sistem akuntansi dan teknologi informasi. Bagi masyarakat kebijakan redenominasi akan mempermudah transaksi ekonomi.

Astrini et al. (2016) melakukan penelitian terkait dampak redenominasi terhadap kinerja perekonomian. Penelitian ini menggunakan data primer yang diperoleh dari percobaan ekonomi dengan menggunakan jenis barang elastis (mobil). Data sekunder dianalisis menggunakan regresi panel statis dengan variabel dependent inflasi. Hasil penelitian menunjukkan bahwa untuk kelompok barang elastis (mobil) penjual cenderung menurunkan harga transaksi dengan tujuan mendapatkan keuntungan yang lebih. Jumlah transaksi cenderung tetap pada kondisi sebelum dan sesudah redenominasi. Selain itu, data sekunder menunjukkan terjadinya penurunan inflasi ketika redenominasi diterapkan.

\section{METODE PENELITIAN}

\section{Jenis dan Sumber Data}

Jenis data yang digunakan adalah data historis beberapa negara yang pernah melakukan redenominasi. Data sekunder yang digunakan adalah tingkat inflasi, pertumbuhan ekonomi, pertumbuhan jumlah uang beredar, tingkat suku bunga riil, tingkat pengangguran, nilai tukar mata uang terhadap Dolar AS, serta indeks bentuk pemerintahan. Penelitian ini juga menggunakan variabel dummy kondisi inflasi (1=inflasi tinggi; dan $0=$ inflasi rendah). Data sekunder diperoleh dari World Development Indicators (WDI). Datadata yang digunakan dalam penelitian ini dapat dilihat di Tabel 3.

Tabel 3 Jenis dan sumber data yang digunakan dalam penelitian

\begin{tabular}{|c|c|c|}
\hline Variabel & Satuan & Sumber \\
\hline Inflasi & rsen & World Development \\
\hline Pertumbuhan ekonomi & & World De \\
\hline $\begin{array}{l}\text { Pertumbuhan jumlah uang beredar } \\
\text { (growth money) }\end{array}$ & persen & World Development Indicators \\
\hline Tingkat suku bunga riil & persen & Wo \\
\hline Ting & rsen & ors \\
\hline ta uang terhadap Dolar & AS) & World D \\
\hline Inde & & elopment In \\
\hline Metode Analisis Data & \multirow{2}{*}{\multicolumn{2}{|c|}{$\begin{array}{l}\text { penelitian ini adalah Microsoft Excel } \\
2010 \text { dan STATA } 14 .\end{array}$}} \\
\hline Penelitian mengenai fakto & & \\
\hline $\begin{array}{l}\text { yang memengaruhi keberhasilan } \\
\text { pelaksanaan redenominasi dianalisis }\end{array}$ & \multicolumn{2}{|r|}{ Model regresi berganda } \\
\hline menggunakan regresi linear be & \multirow{7}{*}{\multicolumn{2}{|c|}{$\begin{array}{l}\text { Pada bagian ini dirumuskan model } \\
\text { untuk melihat faktor-faktor yang } \\
\text { memengaruhi keberhasilan pelaksanaan } \\
\text { redenominasi. Estimasi penelitian pada } \\
\text { bagian ini menggunakan regresi linear } \\
\text { berganda. Variabel eksogen } \\
\text { (independent) adalah pertumbuhan } \\
\text { ekonomi, jumlah uang beredar, nilai }\end{array}$}} \\
\hline Penelitian ini akan mempertimbangkan & & \\
\hline dampak tingkat inflasi, pertumbuhan & & \\
\hline nomi, jumlah uang beredar, tingkat & & \\
\hline & & \\
\hline pemerintahan terhadap kondisi inflasi & & \\
\hline $\begin{array}{l}\text { satu tahun setelah redenomin } \\
\text { Peranokat lunak vang diounakan da }\end{array}$ & & \\
\hline
\end{tabular}


tukar mata uang, serta bentuk pemerintahan.

Sedangkan variabel yang diamati (endogen) atau variabel tak bebas (dependent) adalah keberhasilan atau kegagalan pelaksanaan redenominasi yang diukur oleh tingkat inflasi satu tahun setelah redenominasi diterapkan di masing-masing negara. Penelitian ini juga menggunakan variabel dummy yaitu Dummy (inflasi)i $_{\text {dengan nilai: } 1=}=$ inflasi rendah $(<10 \%)$ dan $0=$ inflasi tinggi $(\geq 10 \%)$. Secara sistematis, model regresi linear berganda yang digunakan untuk mengkaji faktor-faktor yang memengaruhi keberhasilan pelaksanaan redenominasi adalah sebagai berikut:

Infl $_{i}=\alpha_{0}+\alpha_{1}$ Dummy $_{(\text {inflasi)i }}+\alpha_{2}$ Gro $_{i}+$ $\alpha_{3}$ Money $_{i}+\alpha_{4}$ Interest $_{i}+$ $\alpha_{5}$ Unemp $_{i}+\alpha{ } \operatorname{LnEXRi}+$ $\alpha_{7}$ Gove $_{i}+\varepsilon_{i t}$

Keterangan:

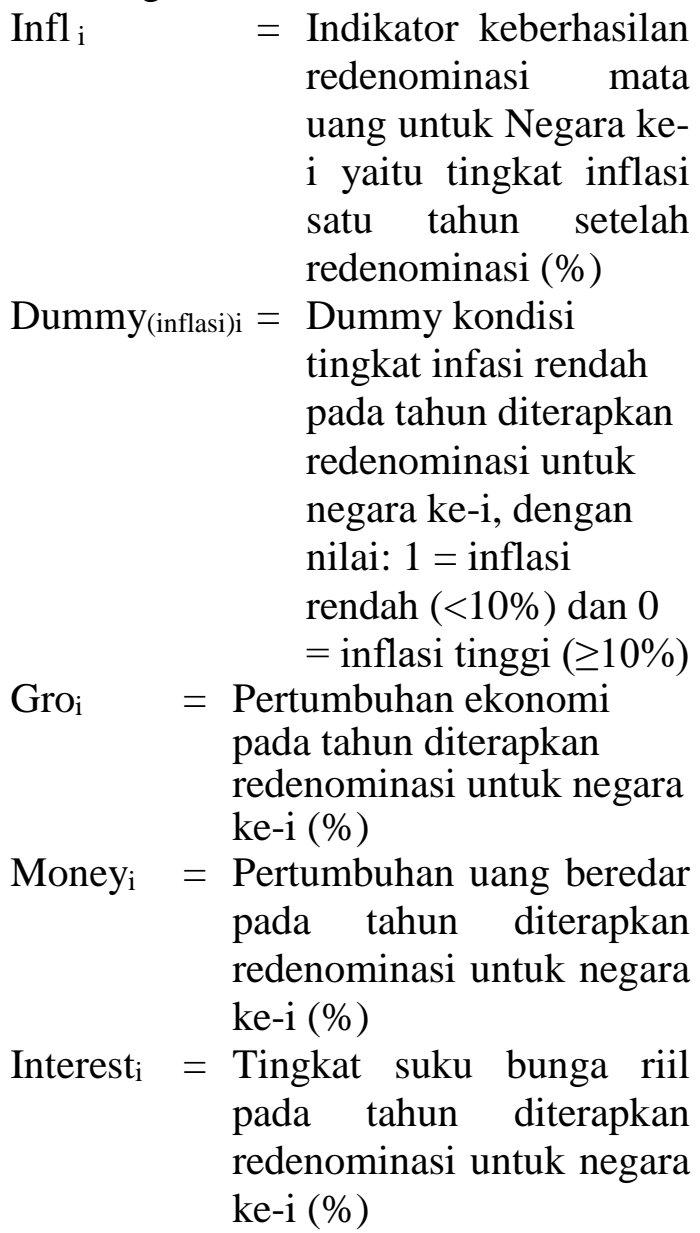

$\begin{aligned} \text { Unemp }_{\mathrm{i}}= & \text { Tingkat pengangguran } \\ & \text { pada tahun diterapkan } \\ & \text { redenominasi untuk negara } \\ & \text { ke-i }(\%) \\ \text { LnEXR }_{\mathrm{i}}= & \text { Logaritma natural nilai } \\ & \text { tukar mata uang terhadap } \\ & \text { dolar pada tahun } \\ & \text { diterapkan redenominasi } \\ & \text { untuk negara ke-i (Uang } \\ & \text { Domestik/ } \$ \text { AS) } \\ = & \text { Indeks bentuk pemerinta- } \\ & \text { han pada tahun diterapkan } \\ & \text { redenominasi untuk negara } \\ & \text { ke-i, dengan nilai min = - } \\ & 10 \quad \text { (sangat autokratis); } \\ \text { Gove }_{\mathrm{i}} & \text { maks = 10 (sangat } \\ & \text { demokratis) } \\ = & \text { konstanta (intercepst) } \\ = & \text { parameter yang diduga } \\ = & \text { random error }\end{aligned}$

Juanda \& Junaedi (2012) menyebutkan bahwa regresi linear berganda harus memenuhi asumsi yang mendasari model. Asumsi tersebut adalah: (a) peubah bebas merupakan peubah non-stokastik (fixed), artinya sudah ditentukan atau bukan peubah acak; (b) tidak ada hubungan linear sempurna antar peubah bebas atau disebut tidak ada masalah kolinier; (c) komponen sisaan $\varepsilon_{\mathrm{i}}$ mempunyai nilai harapan sama dengan nol atau $\mathrm{E}\left(\varepsilon_{\mathrm{i}}\right)=0$; (d) ragam konstan untuk semua pengamatan atau $\operatorname{var}\left(\varepsilon_{\mathrm{i}}\right)=\sigma^{2}$; $€$ tidak ada hubungan/korelasi antar sisaan $\varepsilon_{\mathrm{i}}$ atau $\operatorname{cov}\left(\varepsilon_{\mathrm{i}}, \varepsilon_{\mathrm{j}}\right)=0$ untuk $\mathrm{i} \neq \mathrm{j}$; serta (vi) komponen sisaan menyebar normal.

\section{Analisis ragam.}

Pengujian terkait pengaruh peubah bebas terhadap peubah tak bebas secara simultan dapat diuji dengan menggunakan uji $F$ (analisis ragam). Pengujian secara simultan dimaksudkan untuk melihat pengaruh peubah bebas secara bersama-sama terhadap peubah bebas lainnya. Hipotesis yang 
digunakan untuk melakukan uji $\mathrm{F}$ (analisis ragam) adalah sebagai berikut:

$$
\begin{array}{ll}
\mathrm{H}_{\mathrm{o}} & : \alpha_{1}=\alpha_{2}=\ldots=\alpha_{11} \quad=0 \\
\mathrm{H}_{1} & : \text { minimal ada satu i dimana } \alpha_{\mathrm{i}} \neq 0 \\
& (\mathrm{i}=1,2,3, \ldots, 11)
\end{array}
$$

Hipotesis nol ditolak apabila nilai F-hitung > F-Tabel atau jika peluang nyata (p) lebih kecil dari nilai taraf nyata $(\alpha)$. Jika hipotesis nol ditolak maka dari peubah bebas yang terdapat dalam model tersebut diharapkan terdapat paling sedikit satu peubah yang berpengaruh langsung terhadap peubah tak bebas. Selain itu untuk melihat keterandalan model juga dapat menggunakan koefisien determinasi $\left(\mathrm{R}^{2}\right)$ untuk mengukur proporsi keragaman peubah tak bebas yang dijelaskan oleh model regresi berganda.

\section{Pengujian hipotesis parameter regresi.}

Untuk melihat pengaruh peubah bebas secara parsial selanjutnya dapat menggunakan uji-T. Pengujian ini akan berguna jika pada pengujian analisis ragam diperoleh kesimpulan bahwa terdapat paling sedikit satu peubah bebas yang berengaruh terhadap peubah tak bebas. Uji-T digunakan untuk menunjukkan peubah bebas mana yang berpengaruh terhadap peubah tak bebas. Hipotesis yang digunakan untuk melakukan uji-T adalah sebagai berikut:

$\mathrm{H}_{\mathrm{o}}: \alpha_{1}=0$

$\mathrm{H}_{1}: \alpha_{1} \neq 0(\mathrm{i}=1,2,3, \ldots, 11)$

Statistik uji dapat dirumuskan sebagai berikut:

$$
t=\frac{\widehat{\alpha}_{\mathrm{i}}-\alpha_{\mathrm{i}}}{s_{\widehat{\alpha_{I}}}}
$$

Hipotesis nol akan diterima jika nilai mutlak dari nilai $t$ lebih besar dari nilai t-Tabel atau jika nilai-p lebih kecil dari taraf nyata $(\alpha)$ sebesar $10 \%$ maka hipotesis nol ditolak atau $\mathrm{H}_{1}$ diterima, berarti peubah bebas i berpengaruh terhadap peubah tak bebas jika faktor lainnya tetap (cateris paribus). Nilai-p adalah peluang (risiko) kesalahan dalam menyimpulkan $\mathrm{H}_{1}$.

\section{PEMBAHASAN}

Penelitian ini bertujuan untuk melihat faktor-faktor yang memengaruhi keberhasilan pelaksanaan redenominasi. Model yang digunakan dalam penelitian ini diadaptasi dari model yang digunakan dianalisis menggunakan regresi berganda. Variabel eksogen (independent) adalah pertumbuhan ekonomi, jumlah uang beredar, tingkat suku bunga, tingkat pengangguran, nilai tukar mata uang, serta bentuk pemerintahan. Sedangkan variabel yang diamati (endogen) atau variabel tak bebas (dependent) adalah keberhasilan atau kegagalan pelaksanaan redenominasi yang diukur oleh tingkat inflasi satu tahun setelah redenominasi diterapkan di masing-masing negara. Penelitian ini juga menggunakan variabel dummy yaitu Dummy (inflasi)i dengan nilai: $1=$ inflasi rendah $(<10 \%)$ dan $0=$ inflasi tinggi $(\geq 10 \%)$.

\section{Faktor-faktor yang Memengaruhi Keberhasilan Redenominasi Mata Uang}

Alasan suatu negara melakukan redenominasi mata uang adalah menghentikan atau mengurangi tingkat inflasi yang tinggi, stabilisasi perekonomian, dan meningkatkan kredibilitas mata uang (Mosley 2005). Kriteria berhasil dan gagal dalam melaksanakan redenominasi adalah tingkat inflasi dan lebih rendah dan pertumbuhan ekonomi. Apabila tingkat inflasi lebih rendah dan tingkat pertumbuhan ekonomi stabil maka negara 
tersebut berhasil dalam melaksanakan redenominasi. Sebaliknya, apabila negara tersebut memiliki tingkat inflasi yang lebih tinggi dan pertumbuhan ekonomi yang tidak stabil maka re- denominasi tidak berhasil (gagal). Tabel 4 menunjukkan kriteria berhasil dan tidak berhasil (gagal) beserta negaranya dalam melaksanakan kebijakan redenominasi.

Tabel 4 Kriteria negara berhasil dan gagal dalam melaksanakan redenominasi

\begin{tabular}{|c|c|c|c|c|c|c|c|c|}
\hline \multirow{3}{*}{ Keterangan } & \multicolumn{4}{|c|}{ Berhasil } & \multicolumn{4}{|c|}{ Tidak berhasil } \\
\hline & \multicolumn{2}{|c|}{ Inflasi } & \multicolumn{2}{|c|}{$\begin{array}{c}\text { Pertumbuhan } \\
\text { ekonomi }\end{array}$} & \multicolumn{2}{|c|}{ Inflasi } & \multicolumn{2}{|c|}{$\begin{array}{l}\text { Pertumbuhan } \\
\text { ekonomi }\end{array}$} \\
\hline & Sebelum & Sesudah & Sebelum & Sesudah & Sebelum & Sesudah & Sebelum & Sesudah \\
\hline Rata-rata & 642,07 & 23,98 & 1,01 & 4,45 & 246,78 & 370,92 & 5,41 & 1,65 \\
\hline Maximum & 2741,29 & 20,11 & 4,67 & 1,93 & 1618,43 & $\begin{array}{r}3048,9 \\
7\end{array}$ & 13,66 & 10,03 \\
\hline Minimum & 11,82 & 82,50 & 8,34 & 7,68 & 1,00 & 6,79 & $-0,55$ & $-12,01$ \\
\hline $\begin{array}{l}\text { Standar } \\
\text { Deviasi }\end{array}$ & 835,95 & 20,11 & 4,67 & 1,93 & 500,93 & 943,85 & 4,09 & 5,67 \\
\hline Negara & $\begin{array}{l}\text { Argentina } \\
\text { Lithuania, } \\
\text { Georgia, } \\
\text { Peru, Pol } \\
\text { Ukraina, } \\
\text { Uganda. }\end{array}$ & $\begin{array}{l}\text { Chili, } \\
\text { Bolivia, } \\
\text { srael, Me } \\
\text { ndia, Ron } \\
\text { ruguay, I }\end{array}$ & $\begin{array}{l}\text { Latvia, } \\
\text { Brazil, } \\
\text { cico, Moz } \\
\text { ania, Rus } \\
\text { acedonia, }\end{array}$ & $\begin{array}{l}\text { Belarus, } \\
\text { Bulgaria, } \\
\text { ambique, } \\
\text { a, Turki, } \\
\text { Kroasia, }\end{array}$ & $\begin{array}{l}\text { Azerbaij } \\
\text { Islandia, } \\
\text { Ghana, }\end{array}$ & $\begin{array}{l}\text { 1, Angola } \\
\text { Sudan, F } \\
\text { caragua. }\end{array}$ & $\begin{array}{l}\text { Congo, V } \\
\text { nlandia, }\end{array}$ & $\begin{array}{l}\text { nezuela, } \\
\text { Moldova, }\end{array}$ \\
\hline
\end{tabular}

Penelitian ini menggunakan data historis berupa 32 negara yang pernah melakukan redenominasi sejak tahun 1963 sampai tahun 2008. Menggunakan analisis regresi berganda dalam penelitian ini dilakukan kajian terhadap variabel-variabel ekonomi, yaitu pertumbuhan ekonomi, tingkat suku bunga, jumlah uang beredar, tingkat pengangguran, nilai tukar, bentuk pemerintahan, dan Dummyinflasi. Tabel 5 menunjukkan kondisi perekonomian pada tahun diterapkannya redenominasi mata uang memengaruhi inflasi satu tahun setelah redenominasi tersebut diterapkan.

Berdasarkan Tabel 5, nilai $\mathrm{R}^{2}$ sebesar 98.81\%, artinya $98.81 \%$ variabel tingkat inflasi satu tahun setelah redenominasi dapat dijelaskan oleh semua variabel independen dalam model sedangkan sisanya dijelaskan oleh faktor-faktor lain di luar model. Uji $\mathrm{F}$ bernilai 0.000 dimana lebih kecil dari taraf nyata $10 \%$ maka dalam penelitian ini model tersebut dapat digunakan. 
Tabel 5 Hasil uji regresi linear berganda 32 negara yang telah melakukan redenominasi

\begin{tabular}{llcr}
\hline \multirow{2}{*}{ Variabel } & \multicolumn{3}{c}{ INFLASI $_{1 \text { tahun setelah redenominasi }}$} \\
\cline { 2 - 4 } & Coef & T-stat & Prob \\
\hline Constant & 39,99 & 0,81 & 0,425 \\
Dummy $_{\text {inflasi }}$ & $-8,89$ & $-0,20$ & 0,845 \\
Gro & $-4,89$ & $-1,65$ & $0,113^{* *}$ \\
G_money & 0,37 & 24,44 & $0,000^{*}$ \\
Interest & 0,31 & 1,48 & 0,153 \\
Unemp & 1,85 & 0,58 & 0,570 \\
LnEXR & 2,18 & 0,19 & 0,852 \\
Gove & $-5,84$ & $-1,49$ & $0,148^{* *}$ \\
\hline & & Analisis Ragam & 0,7537 \\
R-Squared & $98,81 \%$ & Sktest & 0,235 \\
R-Squared (Adj) & $98,47 \%$ & Prob (runs test) & 0,9055 \\
F-Statistic & 285,38 & Prob (breusch-pagan) & 2,53 \\
Prob (F-stat) & 0,000 & VIF & \\
\hline Ketang
\end{tabular}

Keterangan: *) signifikansi pada taraf $10 \%$; **) signifikan pada taraf $15 \%$.

Uji normalitas dapat dilihat dari nilai probabilitas sktest sebesar 0,7537 , lebih besar dari taraf nyata $10 \%$ sehingga residual dalam model penelitian ini terdistribusi secara normal. Uji autokorelasi melihat nilai probabilitas p-value dari runs test sebesar 0,235, lebih besar dari taraf nyata $10 \%$. Dapat disimpulkan model ini terbebas dari masalah autokorelasi. Nilai probabilitas breusch-pagan adalah 0,9055 lebih besar dari taraf nyata $10 \%$ sehingga dapat dikatakan bahwa model penelitian tidak mengandung heteroskedastisitas. Berdasarkan uji multikolinearitas, nilai VIF untuk seluruh variabel bebas lebih kecil dari 10 dengan rata-rata sebesar 2,53 maka tidak terjadi multikolinearitas.

Variabel pertumbuhan ekonomi (gro) dan bentuk pemerintahan (gove) signifikan memengaruhi tingkat inflasi satu tahun setelah redenominasi pada taraf nyata $15 \%$. Koefisien pertumbuhan ekonomi bernilai negatif menunjukkan bahwa semakin baik pertumbuhan ekonomi pada saat dilakukan redenominasi, maka tingkat inflasi satu tahun setelahnya akan cenderung menurun. Hal ini sejalan dengan penelitian Mosley (2005) bahwa salah satu faktor yang mendorong keberhasilan redenominasi adalah tingkat pertumbuhan ekonomi yang stabil.

Variabel bentuk pemerintahan (gove) yang dalam penelitian ini diukur menggunakan indeks dengan nilai min $=-10$ (sangat autokratis); maks $=10$ (sangat demokratis) juga signifikan memengaruhi tingkat inflasi satu tahun setelah redenominasi. Koefisien bentuk pemerintahan (gove) bernilai negatif, artinya semakin demokrasi bentuk pemerintahan suatu negara ketika pelaksanaan redenominasi, maka akan menurunkan tingkat inflasi satu tahun setelahnya.

Fenira (2014) menyebutkan bahwa demokrasi akan menurunkan tingkat inflasi karena masyarakat mempercayai pemerintah sepenuhnya. Pemerintahan yang transparan akan membentuk ekspektasi yang baik dari masyarakat kepada pemerintah. Sehingga kebijakan yang dilakukan oleh pemerintah dalam rangka memperbaiki kondisi perekonomian suatu negara akan direspon secara positif oleh masyarakat negara 
tersebut.Variabel yang signifikan mempengaruhi tingkat inflasi satu tahun setelah redenominasi dengan nilai probabilitas di bawah taraf nyata $10 \%$ adalah pertumbuhan jumlah uang beredar (g_money).

Koefisien variabel pertumbuhan jumlah uang beredar (g_money) bernilai positif. Hal ini menunjukkan bahwa negara yang akan melaksanakan redenominasi haruslah menjaga pertumbuhan jumlah uang beredar karena cenderung akan meningkatkan tingkat inflasi satu tahun setelahnya. Mankiw (2007) menyebutkan bahwa terdapat hubungan positif antara jumlah uang beredar dan tingkat inflasi. Ketika jumlah uang beredar mengalami peningkatan, maka akan menyebabkan tingkat inflasi juga mengalami peningktan.

Variabel dummy yang mencerminkan kondisi inflasi (inflasi rendah dan inflasi tinggi) memiliki nilai koefisen $-8,89$. Hal ini berarti bahwa negara yang sedang mengalami inflasi rendah saat redenominasi dilakukan $(<10 \%)$ cenderung memiliki tingkat inflasi satu tahun setelahnya lebih rendah daripada negara yang mengalami inflasi tinggi $(\geq 10 \%)$ dengan rata-rata perbedaan sebesar $8,89 \%$. Namun hasil tersebut memiliki risiko kesalahan 59,5\%. Sejalan dengan Mosley (2005) bahwa redenominasi akan lebih baik dilakukan ketika tingkat inflasi rendah dan pertumbuhan ekonomi stabil.

Kebijakan redenominasi akan menyebabkan money illusion dimana masyarakat akan cenderung membuat kesalahan dalam menilai perubahan nominal atau riil mata uang. Blanchard (2006) menilai bahwa money illusion merupakan biaya dari inflasi. Redenominasi yang dilakukan ketika tingkat inflasi tinggi akan mempersulit masyarakat dalam membandingkan nilai riil sebelum dan sesudah kebijakan. Hal ini karena money illusion akan menyamarkan kenaikan hargaharga yang pada dasarnya disebabkan oleh perilaku produsen yang menganggap bahwa ekspektasi masyarakat terhadap inflasi sudah tinggi sehingga produsen akan meningkatkan harga transaksi suatu barang ketika tingkat inflasi tinggi.

Variabel tingkat suku bunga bernilai 0,31 artinya kenaikan satu persen tingkat suku bunga cenderung akan meningkatkan tingkat inflasi satu tahun setelahnya. Namun variabel tersebut memiliki tingkat kesalahan sebesar 54,5\%. Ketika tingkat suku bunga rendah ketika pelaksanaan redenominasi, banyak dana yang mengalir untuk investasi sehingga pertumbuhan ekonomi akan meningkat. Pertumbuhan ekonomi yang tinggi tersebut cenderung akan menurunkan tingkat inflasi satu tahun setelah redenominasi.

Variabel lainnya adalah tingkat pengangguran yang menunjukkan hubungan positif yaitu sebesar 1,85 . Hal ini menunjukkan bahwa negara yang memiliki tingkat pengangguran yang rendah ketika kebijakan redenominasi diterapkan memiliki kecenderungan akan menurunkan tingkat inflasi satu tahun setelahnya. Dengan kata lain, semakin rendah tingkat pengangguran akan menurunkan tingkat inflasi satu tahun setelah redenominasi diterapkan. Namun variabel ini memiliki tingkat kesalahan sebesar $57 \%$..

Variabel nilai tukar mata uang yang dalam penelitian ini diukur dalam satuan mata uang domestik/US\$ bernilai 2,18. Ketika pelaksanaan redenominasi didukung oleh mata uang yang mengalami apresiasi maka tingkat inflasi satu tahun setelah redenominasi akan menurun. Variabel tersebut memiliki tingkat kesalahan sebesar $85,2 \%$. 
Hasil penelitian menunjukkan bahwa semakin baik kondisi perekonomian suatu negara ketika menerapkan kebijakan redenominasi, maka akan memberikan dampak yang baik. Hal ini ditunjukkan oleh nilai inflasi yang lebih rendah pada saat satu tahun setelah pelaksanaan redenominasi.

\section{KESIMPULAN DAN SARAN}

\section{Kesimpulan}

Berdasarkan hasil analisis regresi berganda yang menggunakan data historis (sekunder), maka dari penelitian ini dapat ditarik kesimpulan sebagai berikut:

Dengan menggunakan data sekunder hasil penelitian menunjukkan bahwa keberhasilan kebijakan redenominasi dipengaruhi oleh kondisi perekonomian suatu negara. Negaranegara yang melakukan redenominasi ketika tingkat inflasinya rendah $(<10 \%)$ cenderung memiliki tingkat inflasi yang lebih rendah pada satu tahun setelahnya daripada negara-negara yang melakukan redenominasi ketika tingkat inflasinya sedang tinggi $(\geq 10 \%)$. Selain itu, semakin baik pertumbuhan ekonomi pada saat dilaksanakan redenominasi akan menurunkan tingkat inflasi satu tahun setelahnya.

\section{Saran}

Berdasarkan hasil penelitian, hal yang paling penting ketika pelaksanakan kebijakan redenominasi adalah kondisi perekonomian negara tersebut. Redenominasi akan lebih baik di-laksanakan dalam kondisi perekonomian yang baik dan stabil yaitu pertumbuhan ekonomi yang tinggi dan tingkat inflasi yang rendah.

Adapun saran untuk penelitian selanjutnya yaitu menambahkan series waktu serta variabel-variabel lainnya yang dianggap dapat berpengaruh terhadap redenominasi.

Pemerintah Indonesia sebaiknya mempersiapkan hal-hal yang kemungkinan akan terjadi apabila redenominasi diterapkan. Oleh sebab itu, sosialisasi secara menyeluruh sangatlah penting untuk dilakukan oleh pemerintah. Hal ini karena banyak masyarakat yang belum paham dan mengerti terkait kebijakan redenominasi yakni pengurangan nominal mata uang Rupiah.

\section{DAFTAR PUSTAKA}

Astrini D, Bambang J, Noer AA. 2016. Impact of redenomination on price, volume, and value of transaction: an experimental economic approach. Buletin Ekonomi Moneter dan Perbankan. 19(2):207-237.

[BI] Bank Indonesia. 2017. Sejarah Bank Indonesia. http://www.bi.go.id [2017 April 05].

Blanchard O. 2006. Macroeconomic- $6^{\text {th }}$ Edition. United States: Prentice Hall.

Daniel W. 2013. Kisah Turki yang Sukses Hilangkan 6 Nol Mata Uangnya. Detik finance [05 Agustus 2010].

Fenira M. 2014. Democracy: A Determinant Factor in Reducing Inflation. International Journal of Economics and Financial Issues 4(2):363-375.

Iona D. 2005. The National Currency Re-denomination Experience in Several Countries: A Comparative Analysis. International Multidisciplinary Symposium Universitaria Simpro. 
Juanda B, Junaidi. 2012. Ekonometrika Deret Waktu Teori dan Aplikasi. Bogor (ID): IPB Press.

Lianto J, Ronald S. 2012. The Impact of Redenomination in Indonesia from Indonesia Citizens' Perspective. Procedia - Social and Behavioral Sciences 40 (2012): 1-6.

Mankiw NG. 2007. Makroekonomi Edisi Keenam. Jakarta (ID): Erlangga.

The World Bank. 2016. "World Development Indicators 2016".

Undang-Undang Republik Indonesia Nomor 6 Tahun 2009 Tentang Bank Indonesia. 13 Januari 2009. Lembaran Negara Republik Indonesia Tahun 2009 Nomor 07. Jakarta.

Zidek L, Chribik M. 2015. Impact of Currency Redenomination on Inflation Case Study Turkey. Asian Economic and Financial Review 5(6):908-914. 